\title{
Analysis of the Value Creation Model in Selected Sectors
}

\author{
Petr SUCHÁNEK, Martin ŠTĚRBA \\ Masaryk University, Brno, Czech Republic \\ suchy@econ.muni.cz, martin.sterba@mail.muni.cz
}

\begin{abstract}
The subject of the article is the analysis of the value creation model (hereinafter referred to as the VCM) in selected sectors of the Czech economy, namely in engineering, transport and the food industry. The aim of the article is to determine the stability of the value creation model in selected sectors over time, i.e. whether the model shows the same explanatory power in different years as in the year in which it was created. The research is based on models the authors created for each sector in 2015 and identifies the explanatory power of these models from 2012 to 2014 based on samples of the respective companies. Thanks to the VCM model being developed and tested along with the EVA indicator, the results of the model from other years under review are equally compared with the EVA results. It turns out that the model is stable in the food industry, i.e. it achieves comparable results in the years 2012 - 2014 as in 2015 , while in the engineering sector it was necessary to modify the model significantly (similarly in transport). It turns out that it is appropriate to specialize complex indices capable of evaluating the performance of companies not only by industry, i.e. the indices are not universal but also in time, that the indices need not be stable (static), but may need to be dynamized.
\end{abstract}

Keywords: Value Creation Model, EVA Ratio, Performance, Food Industry, Transport Industry, Engineering.

\section{$1 \quad$ Introduction}

The subject of the article is the analysis of the value creation model in selected sectors of the Czech economy, namely in engineering, transport and the food industry. The aim of the article is to determine the stability of the value creation model in selected sectors over time, i.e. whether the model shows the same explanatory power in different years as in the year in which it was created. Aggregate business evaluation models are mostly universal — they are intended for cross-sectoral use, and static - as they are used unchanged over the years and are modified from time to time at best. Our research has shown that it is appropriate to modify (adapt) our VCM model based on industry. The question arises whether this model needs to be modified also in different years. The question is answered in this article.

There are a number of concepts and definitions of value [0], depending on the point of view of value, including the place, time and purpose of its definition [0]. In 
our research we focus on value from the point of view of a company, or the financial value of a company as defined by Möller and Törrönen [0], as in monetary units perceived value for a set of economic, technical and other benefits received by the customer in exchange for the price paid for the product offered [0]. In the research, we are interested in the value a company has created in terms of customer payment for the product. This makes it possible to use the financial (accounting) concept, which identifies value as the value of a company's wealth (assets) [0]. There payments are relic of past events, so our concept of value is based on the transaction approach typical of the accounting concept of the value [0]. The accounting concept of value depends on the historical prices recorded through payments / transactions, and these are best traceable in the financial statements that we have chosen to base on. On the other hand, the market value, which includes non-accounting factors such as intellectual capital, is based on the capital market [0], which is not very developed in the Czech Republic.

The accounting concept of value can also be linked to the shareholder value through accounting or measurement based on accounting data [0]. With this in mind, value creation can be focused on the shareholder value and, when assessing it, financial indicators including an EVA indicator based on accounting data can be used. Thus, the EVA indicator is constructed in our research from the ROE indicator (EVA equity) [0].

This synthetic EVA indicator is largely based directly on the evaluation of the ratios. Because the research is based on accounting data of Czech companies and therefore we use Czech accounting standards, there were took over the widely used method of the Ministry of Industry and Trade to calculate the EVA indicator. It allows calculation without further adjustments of financial statemenst [80]. We have put another synthetic indicator against this indicator composed directly of ratios, also based on accounting data, which would then allow us to directly identify the financial value-drivers in the accounting records of the respective businesses. This approach was chosen, for example, by the Neumaiers [0] who, unlike us, designed one universal indicator for all sectors with irregular modifications every few years.

\section{Methodology}

First, the EVA indicator was constructed on the basis of accounting data from the publicly available financial statements of the companies surveyed, followed by the VCM model. Based on the EVA ratios, companies were divided (within the industry) into value-generating and value-destroying businesses and subsequently their agreement with the VCM model was identified. All of this was conducted in the examined years $2012-2014$. In the event of the disagreement of the division by the EVA and the VCM, the VCM model was subsequently modified to increase its explanatory power, i.e. to approximate the division of businesses according to the EVA indicator.

VCM models were developed using the LOGIT logistic regression method. Normality is a prerequisite for logistic regression modeling. In our models this 
prerequisite is fulfilled by taking data from a base set, not from a data selection [0]. Hendl [5] furthermore adds that it is also essential that both possibilities were adequately represented in the data.

First, the EVA indicator [0] separated (eliminated) companies with an unclear economy, i.e. those where ROE was positive and EVA negative, and subsequently companies were divided into value-generating $(\mathrm{EVA}>0)$ and value-destroying $($ EVA $<0)$. Next, a profile analysis was carried out for all companies and financial indicators with the respective weights being obtained by subsequent financial regression, forming a model within the respective sector in 2015. The results obtained were statistically significant at the level of significance $p<0.05$, the value of the chiquadrate was verified and the possible colinearity of the variables in the model was excluded. For each of the three sectors, a separate model was designed.

$$
V C M(\text { Transportation })=\frac{1}{1+e^{-\left(0.865+1.551 * F_{1}+2.012 * F_{2}+0.0002 * F_{3}+0.0002 * F_{4}\right)}}
$$

Where: $F_{1}$ is interest coverage,

$\mathrm{F}_{2}$ is total indebtedness,

$\mathrm{F}_{3}$ is net working capital,

$\mathrm{F}_{4}$ is EBIT.

$V C M($ Food Industry $)=\frac{1}{1+e^{-\left(2.951+0.233 * F_{1}-5.981 * F_{2}-1.247 * F_{3}-0.031 * F_{4}+23.19 * F_{5}+0.14 * F_{6}\right)}}$

Where:

$F_{1}$ is normal liquidity,

$\mathrm{F}_{2}$ is the share of own funds,

$\mathrm{F}_{3}$ is ROS,

$\mathrm{F}_{4}$ is the turnover of assets,

$\mathrm{F}_{5}$ is ROA,

$\mathrm{F}_{6}$ is net profit margin.

$V C M($ Engeneering $)=\frac{1}{1+e^{-\left(3.599-3.75 * F_{1}+4.059 * F_{2}+48.632 * F_{3}+0.127 * F_{4}\right)}}$

Where:

$\mathrm{F}_{1}$ is the cost,

$\mathrm{F}_{2}$ is interest coverage,

$\mathrm{F}_{3}$ is $\mathrm{ROS}$,

$\mathrm{F}_{4}$ is the turnover of equity.

In order to verify the applicability of the above models in the years $2012-2014$, calculations of individual models were made using the financial data of the companies surveyed from the respective years. The first step was to obtain the relevant data via the Magnusweb database. This data was further processed and the value of the necessary indicators for the construction of VCM models and the value of the EVA indicator were calculated. Subsequently, the companies were again divided into 
value-generating and value-destroying according to the EVA indicator and the agreement with the division of companies according to the VCM model in individual years and sectors surveyed was compared.

In case of the low explanatory power of a VCM model, a new model has been designed to increase the accuracy of its explanatory power based on the procedure outlined in the first part of this chapter. Thus, the financial indicators were reevaluated, the new VCM model was designed and its (higher) explanatory power was verified by comparing it with the results achieved according to the EVA indicator.

\subsection{Characteristics of Research Samples}

Company data from the engineering, transport and food industries for 2012, 2013 and 2014 was obtained via the Magnusweb software. Due to the fact that the research builds on our previous research on value creation modeling (VCM model construction for 2015), we searched for data in the same industries that were used in the previous research; thanks to this, we have a predominant proportion of companies in the sample identical to those used in the previous research, and due to the same focus (the same companies in the same industry), the results are also comparable over time.

Table 1. Number of companies per sector in the years under review.

\begin{tabular}{|l|l|l|l|l|}
\hline & 2012 & 2013 & 2014 & Total \\
\hline Transport & 811 & 850 & 807 & 2468 \\
\hline Engineering & 926 & 942 & 957 & 2825 \\
\hline Food & 839 & 861 & 884 & 2584 \\
\hline Total & 2576 & 2653 & 2648 & \\
\hline
\end{tabular}

\section{Results}

This section provides the results of the VCM evaluation for each industry and each year. Due to the lack of the high explanatory power of the model for the engineering sector in the years 2012 - 2014, a new model with a higher level of explanatory power was developed according to the methodology described in the previous chapter.

\subsection{Transport Industry (CZ NACE H 49)}

According to the above methodology, we calculated the value of the indicator and the EVA for each company and divided the companies into groups according to whether the EVA ratio is positive or negative; see Table 2. It is clear from the results that the breakdown of companies is fairly even and comparable in the individual years examined. 
Second, the value of the VCM model was calculated. Table 3 summarizes the results of our calculations. There are always three categories of businesses in the first column. The first line shows companies that create value through their activity. The second line shows companies where it cannot be determined precisely whether the value is created or destroyed, and the conclusion could be misleading; therefore, they are referred to as gray zone businesses. The third group is then formed by businesses that destroy value.

Table 2. EVA ratio in the years under review

\begin{tabular}{|l|l|l|}
\hline EVA value & absolute & relative \\
\hline Year 2012 & $54.9 \%$ \\
\hline Positive & 446 & $45.1 \%$ \\
\hline Negative & 365 & $54.7 \%$ \\
\hline Year 2013 & $45.3 \%$ \\
\hline Positive & 465 & $54.6 \%$ \\
\hline Negative & 385 & $45.6 \%$ \\
\hline Year 2014 & 441 \\
\hline Positive & 366 & \\
\hline Negative &
\end{tabular}

Because it is a linear regression model, the values are calculated using the VCM model in the range from zero to one. The specific limits of each group of businesses in the second column of Table 3 are based on value creation. The third column of the table shows the frequency of businesses in all three groups. The fourth column of the table shows the percentage of the representation of businesses in the whole sample in the year and sector. The last column of the table shows the percentage of agreement between our model and the EVA indicator. In this case, according to our model, 674 companies are marked as value-generating and the EVA model identifies $52.57 \%$ out of these 674 businesses (354 businesses) as value-generating. 
Table 3.1 The results of the model in the years 2012 and 2013

\begin{tabular}{|c|c|c|c|c|}
\hline TRANSPORT 2012 & $\begin{array}{l}\text { VCM } \\
\text { values }\end{array}$ & $\begin{array}{l}\text { Number of } \\
\text { businesses }\end{array}$ & $\begin{array}{c}\% \\
\text { sample }\end{array}$ & Agreemen \\
\hline $\begin{array}{l}\text { area of value-creating } \\
\text { businesses }\end{array}$ & $>0.789$ & 674 & $\%$ & $52.57 \%$ \\
\hline $\begin{array}{l}\text { area of gray-zone } \\
\text { businesses }\end{array}$ & Between & 59 & $7.38 \%$ & $\begin{array}{c}\text { Not } \\
\text { detected }\end{array}$ \\
\hline $\begin{array}{l}\text { area of value-destroying } \\
\text { businesses }\end{array}$ & $<0.167$ & 64 & $8.38 \%$ & $58.21 \%$ \\
\hline \multicolumn{5}{|l|}{ TRANSPORT 2013} \\
\hline $\begin{array}{l}\text { area of value- creating } \\
\text { businesses }\end{array}$ & $>0.789$ & 771 & $\%$ & $57.10 \%$ \\
\hline $\begin{array}{l}\text { area of gray-zone } \\
\text { businesses }\end{array}$ & Between & 70 & $7.77 \%$ & $\begin{array}{c}\text { Not } \\
\text { detected }\end{array}$ \\
\hline $\begin{array}{l}\text { area of value-destroying } \\
\text { businesses }\end{array}$ & $<0.167$ & 60 & $6.66 \%$ & $56.79 \%$ \\
\hline
\end{tabular}

Table 3.2 The results of the model in the year 2014

\begin{tabular}{|c|c|c|c|c|}
\hline \multicolumn{2}{|c|}{ TRANSPORT 2014 } & 673 & $\begin{array}{c}84.6 \\
5 \%\end{array}$ & $57.40 \%$ \\
\hline $\begin{array}{c}\text { area of value-creating } \\
\text { businesses }\end{array}$ & $>0.789$ & 61 & $\begin{array}{c}7.67 \\
\%\end{array}$ & $\begin{array}{c}\text { Not } \\
\text { detected }\end{array}$ \\
\hline $\begin{array}{c}\text { area of gray-zone } \\
\text { businesses }\end{array}$ & Between & 61 & 7.67 & $60.19 \%$ \\
\hline $\begin{array}{c}\text { area of value- } \\
\text { destroying businesses }\end{array}$ & $<0.167$ & & & \\
\hline
\end{tabular}

Even though there is a strong agreement between the VCM and the EVA at first glance, the explanatory power of this model was weak in all three years. According to the results, it can be deduced that it was mainly due to the setting of its limits. These were too soft for assessment (few companies were evaluated negatively by the model compared to the EVA indicator), thus causing a disproportionate increase in the number of businesses identified by the model as value-generating. This can be explained by the fact that in 2015 , based on whose data the model was created, the value-generating businesses were worse, therefore the limits were set higher than appropriate for previous years. This can be documented by the EVA average values of this industry, which declined year-on-year from CZK 3,013,685 in 2012 to CZK $14,021,767$ in 2015.

Therefore, how to set limits for each year needs to be considered. An ideal, but intricately feasible way is to create an algorithm for automatic limit adjustment based on the years and average industry performance, i.e. the dynamization of this static model. Then, it would be necessary to find the factors that changed over the years, by 
how much they have changed and how (how much) they affected the financial indicators contained by the VCM model.

\subsection{Engineering, the Original Model (CZ NACE C 27, C 28)}

In engineering, EVA indicators were first calculated as well. There is a clear trend showing that a higher percentage of businesses generate value, and thus that the state of engineering is improving. This is, however, somewhat in contrast with the average value of the EVA indicator in the industry, which continuously declined year-on-year from CZK 4,102,168 in 2012 to CZK 2,488,235.5 in 2015.

Table 4. EVA ratio in the years under review

\begin{tabular}{|l|l|l|}
\hline EVA value & absolute & relative \\
\hline Year 2012 & $55.3 \%$ \\
\hline Positive & 512 & $44.7 \%$ \\
\hline Negative & 414 & $59.5 \%$ \\
\hline Year 2013 & $40.5 \%$ \\
\hline Positive & 560 & \\
\hline Negative & 382 & $62.8 \%$ \\
\hline \multicolumn{2}{|l}{} \\
\hline Year 2014 & 601 & $37.2 \%$ \\
\hline Positive & 356 & \\
\hline Negative &
\end{tabular}

As the following table shows, the 2015 engineering model turned out poorly (in terms of its low explanatory power) in 2012 - 2014 and, therefore, we decided to create a new model that should have a better ability to discriminate between businesses over the period under review.

Table 5. The results of the model in the years under review

\begin{tabular}{|c|c|c|c|c|}
\hline Engineering 2012 & $\begin{array}{c}\text { VCM } \\
\text { values }\end{array}$ & $\begin{array}{c}\text { Number of } \\
\text { businesses }\end{array}$ & $\begin{array}{c}\% \\
\text { sample }\end{array}$ & Agreement \\
\hline $\begin{array}{c}\text { area of value-generating } \\
\text { businesses }\end{array}$ & $<0.248$ & 93 & 10.04 & $\%$ \\
\hline $\begin{array}{c}\text { area of gray-zone } \\
\text { businesses }\end{array}$ & Between & 0 & $0.00 \%$ & Not detected \\
\hline $\begin{array}{l}\text { area of value-destroying } \\
\text { businesses }\end{array}$ & $>0.502$ & 833 & 89.96 & $\%$ \\
\hline Engineering 2013 & 82 & $8.70 \%$ & $74.83 \%$ \\
\hline area of value-generating & $<0.248$ & $82 \%$ \\
\hline
\end{tabular}




\begin{tabular}{|c|c|c|c|c|}
\hline businesses & & & & \\
\hline \begin{tabular}{|cc} 
area of gray-zone \\
businesses
\end{tabular} & Between & 0 & $0.00 \%$ & Not detected \\
\hline $\begin{array}{l}\text { area of value-destroying } \\
\text { businesses }\end{array}$ & $>0.502$ & 860 & $\%$ & $62.67 \%$ \\
\hline Engineering 2014 & & & & \\
\hline $\begin{array}{l}\text { area of value-generating } \\
\text { businesses }\end{array}$ & $<0.248$ & 59 & $6.17 \%$ & $67.71 \%$ \\
\hline $\begin{array}{l}\text { area of gray-zone } \\
\text { businesses }\end{array}$ & Between & 0 & $0.00 \%$ & Not detected \\
\hline $\begin{array}{l}\text { area of value-destroying } \\
\text { businesses }\end{array}$ & $>0.502$ & 897 & $\begin{array}{r}93.83 \\
\%\end{array}$ & $64.54 \%$ \\
\hline
\end{tabular}

\subsection{Engineering, the New Model (CZ NACE C 27, C 28)}

The financial data for 2015 and 2014 were used to create the model, and we proceeded in the same way (profile analysis, logistic regression, testing) when designing it as in the previous research (when constructing the original VCM models).

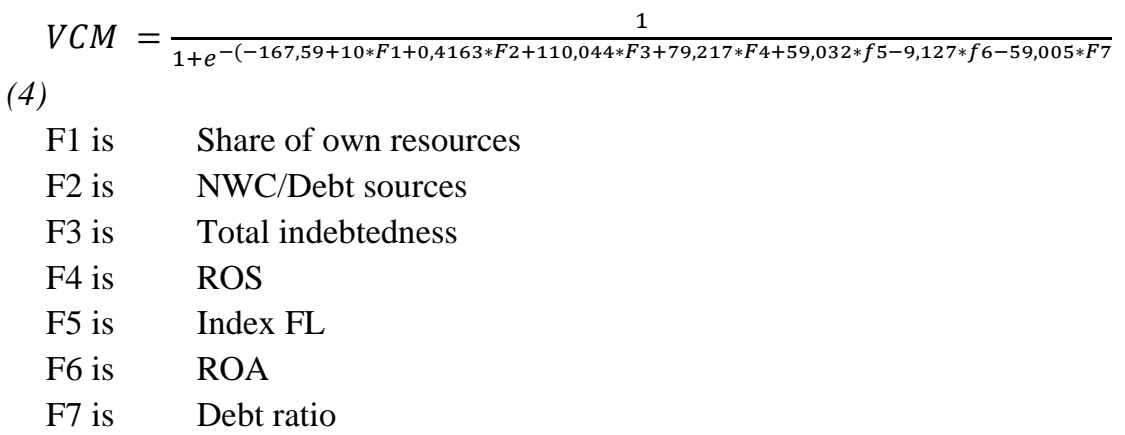

As the formula shows, the new model has been enlarged by three financial indicators, which should ensure improved accuracy over a longer period. At the same time, the structure of the financial indicators of the model changed completely (only the ROS indicator remained).

Table 6. The results of the model in the years under review

\begin{tabular}{|c|c|c|c|c|}
\hline Engineering 2012 & $\begin{array}{c}\text { VCM } \\
\text { values }\end{array}$ & $\begin{array}{c}\text { Number of } \\
\text { businesses }\end{array}$ & $\begin{array}{c}\% \\
\text { sample }\end{array}$ & Agreement \\
\hline $\begin{array}{c}\text { area of value- creating } \\
\text { businesses }\end{array}$ & $>0.985$ & 421 & 45.47 & $\%$ \\
\hline area of gray-zone & Between & 229 & 29.81 & Not detected \\
\hline
\end{tabular}




\begin{tabular}{|c|c|c|c|c|}
\hline businesses & & & $\%$ & \\
\hline $\begin{array}{l}\text { area of value-destroying } \\
\text { businesses }\end{array}$ & $>0.816$ & 276 & $\%^{24.73}$ & $73.92 \%$ \\
\hline \multicolumn{5}{|l|}{ Engineering 2013} \\
\hline $\begin{array}{l}\text { area of value- creating } \\
\text { businesses }\end{array}$ & $>0.985$ & 435 & $\%^{46.18}$ & $80.01 \%$ \\
\hline $\begin{array}{|cc|}\text { area of gray-zone } \\
\text { businesses }\end{array}$ & Between & 213 & $\%^{22.46}$ & Not detected \\
\hline \begin{tabular}{|l|} 
area of value-destroying \\
businesses
\end{tabular} & $>0.816$ & 294 & $\%^{31.12}$ & $74.83 \%$ \\
\hline \multicolumn{5}{|l|}{ Engineering 2014} \\
\hline \begin{tabular}{|l|} 
area of value- creating \\
businesses
\end{tabular} & $>0.985$ & 510 & $\%^{55.07}$ & $78.43 \%$ \\
\hline $\begin{array}{|cc|}\text { area of gray-zone } \\
\text { businesses }\end{array}$ & Between & 241 & $\%^{24.92}$ & Not detected \\
\hline $\begin{array}{l}\text { area of value-destroying } \\
\text { businesses }\end{array}$ & $>0.816$ & 206 & $\%^{20.01}$ & $74.61 \%$ \\
\hline
\end{tabular}

The new model is much more suited for the years examined and achieves an accuracy close to $80 \%$. Moreover, it is able to achieve this value throughout the period. However, it is clear that the gray zone is extensive in this model. The question becomes why the gray zone is not similarly large in other models as well. This is probably due to large differences between engineering companies, which is caused by the inclusion of two groups of companies (the manufacturing of electrical equipment - C27 and the manufacturing of machinery and equipment - C28) with significant differences in the average value of the EVA indicator (e.g. in 2015, the value of the indicator for C27 is CZK 5,484,624 and for C28 CZK -508,153). The model is then not able to classify businesses exactly into categories. Further, we can see the higher rigidity of the VCM model compared to the EVA indicator. However, this may not be bad because a large part of businesses determined by EVA as value-generating fall in the case of the VCM model into the gray zone.

\subsection{Food Industry (CZ NACE C 10, C 11)}

There is a trend regarding the improvement of the surveyed businesses also in the food sector, where $48 \%$ of EVA positive businesses observed in 2012 increased to $57 \%$ in 2014. In this case, the average value of the indicator only declined from 2012 (from CZK 3,258,000.5) to 2014 (to CZK -2,089,074.5), with an increase to CZK $1,190,751.5$ in 2015 . In this respect, the food industry is somewhat apart from the other two sectors. 
Table 7. EVA ratio in the years under review

\begin{tabular}{|l|l|l|}
\hline EVA value & absolute & relative \\
\hline Year 2012 & $47.92 \%$ \\
\hline Positive & 402 & 52.08 \\
\hline Negative & 437 & $52.01 \%$ \\
\hline Year 2013 & $47.99 \%$ \\
\hline Positive & 453 & $56.56 \%$ \\
\hline Negative & 418 & $43.44 \%$ \\
\hline Year 2014 & \\
\hline Positive & 500 & \\
\hline Negative & 384 & \\
\hline
\end{tabular}

Also, the food industry model identified a positive trend in the surveyed companies, with the share of generating businesses growing and destroying businesses declining. The gray zone share stagnated.

Table 8. The results of the model in the years under review

\begin{tabular}{|c|c|c|c|c|}
\hline Food industry 2012 & \begin{tabular}{|l} 
VCM \\
values
\end{tabular} & $\begin{array}{l}\text { Number of } \\
\text { businesses }\end{array}$ & $\begin{array}{c}\% \\
\text { sample }\end{array}$ & Agreement \\
\hline $\begin{array}{l}\text { area of value- creating } \\
\text { businesses }\end{array}$ & $>0.912$ & 257 & $\%^{31.23}$ & $82.88 \%$ \\
\hline \begin{tabular}{|l} 
area of gray-zone \\
businesses
\end{tabular} & Between & 141 & $\%$ & Not detected \\
\hline $\begin{array}{l}\text { area of value-destroying } \\
\text { businesses }\end{array}$ & $<0.818$ & 425 & $\%$ & $76.23 \%$ \\
\hline \multicolumn{5}{|l|}{ Food industry 2013} \\
\hline $\begin{array}{l}\text { area of value- creating } \\
\text { businesses }\end{array}$ & $>0.912$ & 311 & $\%^{36.12}$ & $83.92 \%$ \\
\hline $\begin{array}{ll}\begin{array}{c}\text { area of gray-zone } \\
\text { businesses }\end{array} & \\
\end{array}$ & Between & 138 & $\%$ & Not detected \\
\hline $\begin{array}{l}\text { area of value-destroying } \\
\text { businesses }\end{array}$ & $<0.818$ & 412 & $\%$ & $74.17 \%$ \\
\hline \multicolumn{5}{|l|}{ Food industry 2014} \\
\hline $\begin{array}{l}\text { area of value- creating } \\
\text { businesses }\end{array}$ & $>0.912$ & 356 & $\%$ & $85.112 \%$ \\
\hline $\begin{array}{|cc|}\text { area of gray-zone } \\
\text { businesses }\end{array}$ & Between & 163 & $\%$ & Not detected \\
\hline $\begin{array}{l}\text { area of value-destroying } \\
\text { businesses }\end{array}$ & $<0.818$ & 358 & $\%^{40.82}$ & $74.52 \%$ \\
\hline
\end{tabular}


The food industry model seems to be the most valuable model. It is based on data from 2015 , but maintains a high accuracy of up to $85 \%$ over the period under review. This model leads us to consider whether the aspect of changes in the sector or the susceptibility of the sector to cyclicality is important for modeling. This reflection should be developed through further research, especially in the context of the different sectoral development indicated by the renewed increase in the average value of the EVA indicator.

\section{Discussion}

The results confirm the need to construct different synthetic models for different industries. Although the variants of the VCM model are similar, they are not the same and do not work with the same indicators. It can be deduced that the more diverse the industries are, the more suitable it is to construct separate synthetic indicators, or variants.

It also appears that in some cases (food, and to some extent the transport industry) it is possible to use the same model in different years without losing its explanatory power. In contrast, in some industries (here, engineering) it is appropriate and necessary to construct a separate variant of the model in order to maintain the high explanatory power of the model.

The cause of these results could be the dynamics of changes taking place in the sector, or the environment in which the business operates and their direction and impact on the internal functioning of these businesses, which are subsequently reflected in financial indicators and in the ability to generate value. In this respect, there seems to have been radical changes in engineering during the period under review, which were fully demonstrated in the industry and businesses in 2015. The years $2012-2014$ could be identified as relatively quiet in this sector at first glance as the new VCM constructed from the values of 2014 and 2015 achieved a very good level of explanatory power.

Nevertheless, 2012 - 2014 were not stable in terms of the evolution of the EVA indicator. This is evident in the development of the EVA indicator, whose average value in engineering in $2012-2015$ continued to decline (the relative drop of the indicator was almost by $40 \%$ ). However, the value of the EVA indicator declined steadily and the dynamics of the change tended to decline. It can be deduced from this that the level of change is important for the explanatory power of the VCM model, while a relatively high degree of change that causes the decline in the explanatory power of the VCM model needs to be reflected in its construction. It is insignificant whether the change has taken place quickly or gradually; the essential aspect is that it has gone beyond the limit after which the VCM model needs to be modified.

But the question becomes how to determine this limit? It is obvious that changes must be reflected in altering the financial indicators used in the VCM model. But once more, the question arises as to how to identify which factors and the extent of their effect on the financial indicators (parameters). 
The problem of the trend can be illustrated by the food industry, which declined significantly between 2012 and 2014 according to the EVA average values, but increased again in 2015. This was probably the cause (including the stability of the financial value-generating indicators - see below) of the solid explanatory power of the VCM model in years under review other than 2015.

Another problem is that the original and the new VCM model for engineering differs significantly both in terms of the number of financial indicators (originally 4 indicators, newly 7 indicators) and the structure (in both models there is only one common ROS indicator). In this case, the modification of the model is not only about modifying the parameters, but basically constructing a new VCM model. Again, however, the question arises as to how to determine that it is time to change the model, i.e. how to detect that some of the current financial indicators in the VCM model wrongly reflect value creation, or that the focus of the value creation has transferred elsewhere?

Unlike in the engineering sector, there was a much more radical decrease in the average value of EVA in the transport sector. Still, the model designed for 2015 was also usable (albeit in a limited way) for the other years surveyed. It seems that in this case, the financial indicators identifying value creation remained the same (as in the food industry) and only the change of the limits or parameters of the VCM model can be considered.

\section{Conclusion}

The results clearly show that if it proved effective to construct different VCM models within each sector, there is no such agreement in the case of a time-on-time change. Research shows that there are sectors for which it is not necessary to recalculate the results in the short term (annually), or to always construct new VCM models (the food industry). Similarly, there are sectors for which it is necessary (engineering). Finally, there are also sectors for which it is not necessary; however, the explanatory power of the model is so low that it would be advisable to at least consider it.

The problem seems to consist of the stability of the sector's environment in relation to the financial indicators that enter into the VCM in each sector. It is possible to hypothesize that the higher stability of the environment, i.e. the fewer factors affect the relevant financial indicators of the VCM model, the more stable the model is over time and does not need to be changed or modified.

From this point of view, engineering seems to be a more dynamic sector than transport, whereas the latter seems more dynamic than the food industry. Interestingly, the results of the VCM model (calculated from data for 2015) for engineering show that the performance of businesses in 2012-2014 was higher than in 2015 (the same can be said about the transport industry).

In further research, it would be appropriate to consider which factors affect the financial indicators of the models and how and how much they affect the financial indicators of the VCM models. The related question is how the weights of the individual parameters (financial indicators) - value holders can be made dynamic. 
There is a possibility to examine the industry as a whole and the average values of the financial indicators, or to examine the values of the entire economy, led by factors such as GDP, inflation and others, and to estimate their impact on the financial indicators used in the model. Last but not least, it will be necessary to examine whether there are universal indicators indicating value creation, whether these indicators change, how they change and why.

Acknowledgements. This article is an output from the project "Přístup managementu k redukci zpětných toků ve vazbě na spokojenost zákazníků a neustálé zlepšování," Czech Science Foundation no. GA 16-16260S.

\section{References}

1. Anderson, J. C., Jain, D. C., Chintagunta, P. K.: Customer value assessment in business markets: A state-of-practice study. Journal of Business-to-Business Marketing, 1(1), 3-29. (1992)

2. Edvinsson, L. and Malone, M.S.: Intellectual Capital: Realizing Your Company's True Value by Finding Its Hidden Brainpower, Harper Business, New York, NY. (1997)

3. Ezzamel, M., Willmott, H., Worthington, F.: Manufacturing shareholder value: The role of accounting in organizational transformation. Accounting, Organizations and Society, 33(2), 107-140. (2008)

4. Gretl. gretl.sourceforge.net [software]. November 2016.

5. Hendl, J.: Přehled statistických metod: analýza a metaanalýza dat. 4., rozš. vyd. Praha: Portál, ISBN 978-80-262-0200-4. (2012)

6. Möller, K. K., Törrönen, P.: Business suppliers' value creation potential: A capabilitybased analysis. Industrial Marketing Management, 32(2), 109-118. (2003)

7. Neumaierová, I. Neumaier, I.: Výkonnost a tržní hodnota firmy. 1. vyd. Praha: Grada, 216 p.(2002)

8. Odbor ekonomických analýz: Finanční analýza podnikové sféry za rok 2016. Ministerstvo průmyslu a obchodu. (2017)

9. Pecáková, I.: Logistická regrese s vícekategoriální vysvětlovanou proměnnou. Acta Oeconomica Pragensia. 2007, 15(1): 86-96. ISSN 1804-2112. (2007)

10. Procházka, D.: Readiness for the voluntary adoption of the IFRS by non-listed companies: a Czech perspective. Recent Res Appl Econ WSEAS, 3: 81-86. (2011)

11. Suchánek, P., Šterrba. M.: The Efficiency of the Value Creation Model in the Manufacturing Industry in the Czech RepublicProceedings of International Scientific Conference of Business Economics Management and Marketing 2017. 1. vyd. Brno: Masaryk University, 2017. pp. 273-283, 11 s. ISBN 978-80-210-8714-9. (2017)

12. Varaiya, N., Kerin, R. A., Weeks, D.: The relationship between growth, profitability, and firm value. Strategic Management Journal, 8(5), 487-497. (1987).

13. Wilson, D. T., Jantrania, S.: Understanding the value of a relationship. Asia-Australia marketing journal, 2(1), 55-66, (1994). 